\title{
OXYGEN ISOTOPES IN DIFFERENT RECESSION SUBREGIMES OF KARST SPRINGS IN THE BREZOVSKÉ KARPATY MTS. (SLOVAKIA)
}

\author{
IZOTOPI KISIKA V RAZLIČNIH PODREŽIMIH RECESIJE \\ KRAŠKIH IZVIROV V BREZOVSKIH KARPATIH (SLOVAŠKA)
}

\author{
Peter MALÍK ${ }^{1} \&$ Juraj MICHALKO ${ }^{2}$
}

\begin{abstract}
UDC 556.3(437.6)

Peter Malik \& Juraj Michalko: Oxygen Isotopes in Different Recession Subregimes of Karst Springs in the Brezovské Karpaty Mts. (Slovakia)

Karst spring hydrograph separation method based on quick iterative solution of several simple exponential and linear equations, was developed for linking small datasets of samples to various hydrologic situations. The method is based on a presumption, that a spring's discharge depends on the level of aquifer saturation by groundwater, and that the same discharge reflects the same groundwater saturation (piezometric level) in the aquifer. Every spring can be described by unique sets of constant starting discharges, $Q_{0}$ values, recession coefficients a (laminar flow components in exponential equations), and $\beta$ (turbulent flow components in linear equations). Each subregime can be detected by recession curve analyses of the complete spring's discharge time series. In this hydrograph separation, every measured discharge value, $Q_{t}$ is then determined by a representative time, $\boldsymbol{t}$; i.e., theoretical elapsed time $\mathrm{t}$ from the total maximum discharge value $Q_{\max }$. The aim of the iteration process is to obtain this representative time $t$ for each discharge. The individual flow components are calculated using the same $t$ value. These variances in subregime discharges in a certain moment can be linked to the components analysed in the same moment, in order to obtain the end members of the theoretical mixture. This technique was developed and applied on the discharge time series of the four karstic springs in the Brezovské Karpaty Mts. (Slovakia), built mainly by karstified Middle and Upper Triassic dolomites and limestones. Groundwater of individual springs were characterised by $\delta^{18} \mathrm{O}$ (SMOW) and groundwater temperature values and end members of two laminar and one turbulent subregimes were calculated. Results were based on sparsely populated datasets and manual discharge records, but represent a perspective method for future development and interpretations on limited dataset results.
\end{abstract}

Keywords: groundwater, hydrograph separation, recession curves, oxygen isotopes, Brezovské Karpaty Mts., Slovakia.
Izvleček

UDK 556.3(437.6)

Peter Malik \& Juraj Michalko: Izotopi kisika v različnih podrežimih recesije kraških izvirov v Brezovskih Karpatih (Slovaška)

Za povezovanje majhnih podatkovnih skupin vzorcev $\mathrm{z}$ različnimi hidrološkimi razmerami je bila razvita metoda separacije hidrograma kraških izvirov, ki temelji na hitrem iterativnem reševanju več enostavnih eksponentnih in linearnih enačb. Metoda temelji na predpostavki, da je pretok izvira odvisen od stopnje zasičenosti vodonosnika s podzemno vodo, in da je enak pretok posledica enake zasičenost vodonosnika s podzemno vodo (piezometrični nivo). Vsak izvir lahko opišemo z edinstvenim nizom konstantnih začetnih pretokov, vrednosti $Q_{0}$, koeficientov recesije a (komponente laminarnega toka v eksponentnih enačbah) in $\beta$ (komponente turbulentnega toka $\mathrm{v}$ linearnih enačbah). Vsak podrežim lahko določimo $\mathrm{z}$ analizo krivulje recesije za celotne časovne serije pretokov izvirov. Pri tej separaciji hidrograma je vsaka merjena vrednost pretoka, $Q_{p}$ določena z reprezentativnim časom, $\boldsymbol{t}$; to je teoretično preteklim časom $t$ od skupnega maksimalnega pretoka $Q_{\max }$. Namen procesa iteracije je dobiti ta reprezentativni čas $\mathrm{t}$ za vsak pretok. Posamezne komponente toka so izračunane $\mathrm{z}$ uporabo istih vrednosti t. Te spremembe $\mathrm{v}$ pretokih podrežima $\mathrm{v}$ določenem trenutku lahko povežemo s komponentami, analiziranimi v istem trenutku, da bi dobili končne člene teoretične mešanice. Ta tehnika je bila razvita in uporabljena na časovnih serijah pretokov štirih kraških izvirov v Brezovskih Karpatih (Slovaška), ki jih gradijo predvsem zakraseli srednje in zgornje triasni dolomiti in apnenci. Podzemna voda posameznih izvirov je bila opredeljena $z$ vrednostmi $\delta^{18} \mathrm{O}$ (SMOW) in temperature, izračunani pa so bili končni členi dveh laminarnih in enega turbulentnega podrežima. Rezultati temeljijo na redkih nizih podatkov in ročno izmerjenih pretokih, a predstavljajo perspektivno metodo za nadaljnjo obdelavo in intepretacijo pri omejeni količini podatkov.

Ključne besede: podzemna voda, separacija hidrograma, krivulje recesije, izotopi kisika, Brezovski Karpati, Slovaška.

\footnotetext{
${ }^{1}$ State Geological Institute of Dionýz Štúr, Mlynská dolina 1 Bratislava, Slovakia, e-mail: peter.malik@geology.sk

${ }^{2}$ State Geological Institute of Dionýz Štúr, Mlynská dolina 1, Bratislava, Slovakia, e-mail: juraj.michalko@geology.sk

Received/Prejeto: 5.11.2009
} 


\section{INTRODUCTION}

Hydrograph separation procedures have commonly been used to define separate exponential terms, and the different components interpreted as indicators of different flow components of recessions (Tallaksen 1995). Interpreting recession flow using graphical techniques has been frequently applied to distinguish between different flow components or for separation of the total hydrograph (Kulandaiswamy \& Seetharaman 1969; Linsley et al. 1982; Bates \& Davies 1988). However, graphical separation methods are usually highly subjective and are of limited use as indicators of the flow processes. Hydrograph separation methods presented by James and Thompson (1970), Browne (1978), Pereira and Keller (1982) focus on base flow recessions, and do not attempt to model a continuous separation, as they abandon subjective methods for analysing compound recession curves in favour of analytic separation procedures. Evaluation of automated techniques for base flow and recession analyses introduced a principle of master recession curve and its automated determination (Nathan \& McMahon 1990; Lamb \& Keith 1997; Rutledge 1998; Posavec et al. 2006).

Methods of hydrograph separation are broadly used, especially to determine the baseflow component in stream flow (e.g., Chapman 1999; Wittenberg \& Sivapalan 1999). Pereira (1977) developed a least-squares approach in order to obtain recession parameters that characterize recession in small mountain basins, based on the solution of two exponential equations. The USGS Hydrograph Separation Program (HYSEP; Sloto \& Crouse 1996) performs hydrograph separation, estimating the groundwater (baseflow) component of streamflow using techniques of Pettyjohn and Henning (1979) - fixed interval, sliding interval, or local minimum.

Separation of karst hydrographs into components is mostly based on analogy with surface stream flows. Baseflow in karst hydrogeology is typically composed of discharges from small joints and clastic deposits. Surface flow and interflow from the surface water hydrograph can be linked to newly infiltrated water from the recharge event and/or long-resident water replaced by rapidly transmitted potentiometric effect of recharge event. Thus, separation of hydrograph on the bases of water resident time is equally important for the evaluation of groundwater quality and quantity (Kresic 1993).

For hydrograph component separation, Drogue (1972) proposed application of hyperbolic function of Boussinesq type with power coefficients having values $0.5,1.5$ and 2. Yevjevich (1976) introduced a schematic decomposition of unit hydrograph response of a karst aquifer with several subregimes: very slow response of finest fissures and clay-silt deposits; slow response of silt and sand deposits and medium sized fissures; medium, rapid-to-slow response of sand-to-gravel deposits and medium sized fissures; rapid response of large channels and enlargements. The majority of authors concentrated on hydrograph separation via comparison of groundwater quality and discharge, using both water chemistry and isotope data (Hino \& Hasebe 1986; Hooper \& Shoemaker 1986; Dreiss 1989; Lakey \& Krothe 1996; Talarovich \& Krothe 1998; Trček et al. 2006). Király (2003) criticises substitution of the "old water" component concept and the base-flow concept. For the same hydrograph, a very different dilution, depending on saturated aquifer volume, affects the "old water" component. In this way, the relation of groundwater quality and discharge is strongly affected by dilution and water mixing processes within the aquifer and it is difficult to estimate the "end members" in the springing groundwater mixture.

When data is limited to discharge, it is still useful to develop a hydrograph separation method to serve in situations with limited water quality data, in order to link them to quantitatively defined flow components. In this paper, we tried to develop a method based on quick iterative solutions of simple equation sets, and to test it on an example of small dataset gathered in the Brezovské Karpaty Mts. two decades ago.

\section{SITE DESCRIPTION}

Forested hills of the Slovakian Brezovské Karpaty Mts. (Fig. 1, max. $585 \mathrm{~m}$ asl), neighbouring the northern Slovakian - part of the Vienna Basin, are built mainly by karstified Middle and Upper Triassic dolomites and limestones, outcropping on $77.4 \mathrm{~km}^{2}$. Adjacent (possibly drained) area can be extended to $193.3 \mathrm{~km}^{2}$, with average altitude of $318.1 \mathrm{~m}$ asl. Mean altitude of the Trias- sic carbonate range is $344.0 \mathrm{~m}$ asl (Malík et al. 1992). In the centre of the area, the name of ancient municipality Dobrá Voda (Good Quality Water in translation) designates the regional importance from the drinking groundwater supply point of view (Fig. 2). Carbonate permeability is generally very high, but there are considerable differences between limestones and dolo- 

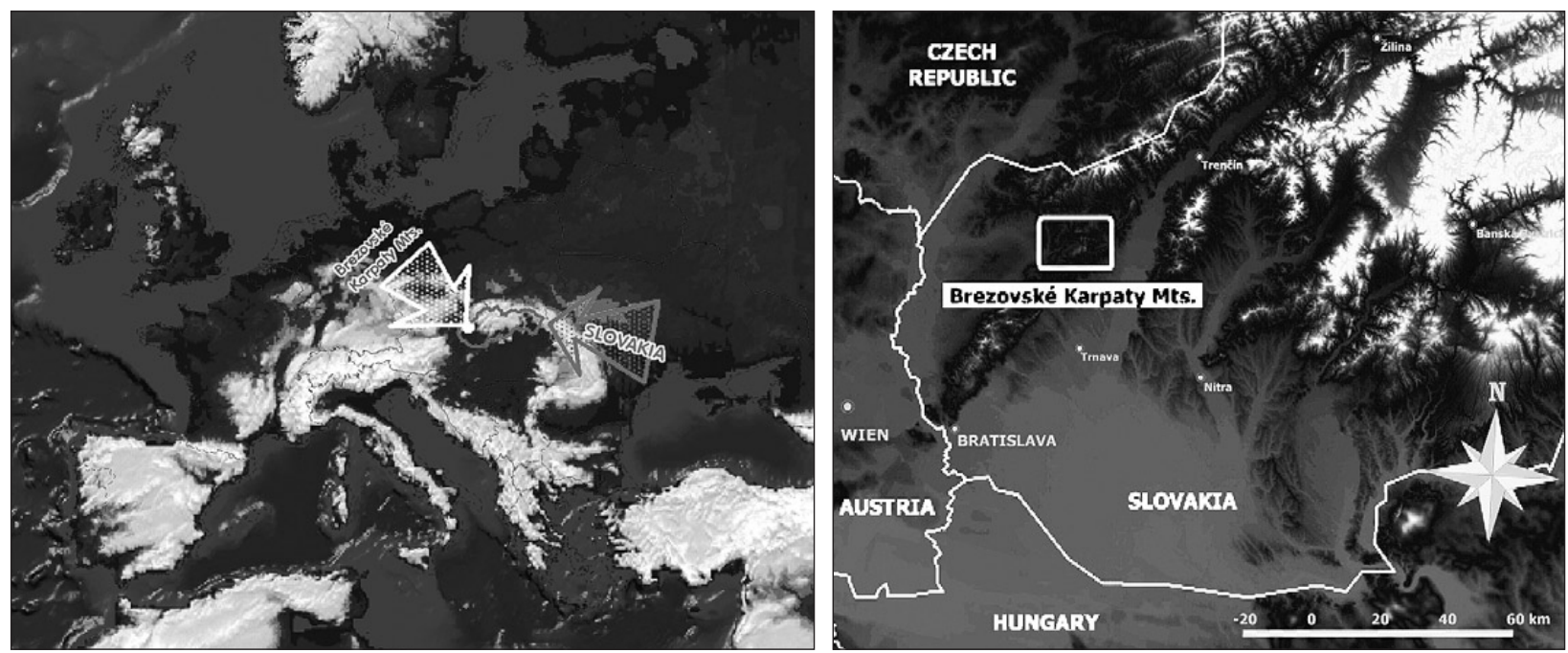

Fig. 1: Position of the investigated area - Brezovské Karpaty Mts. (Slovakia).

mites (Guttenstein/Annaberg, Schreyeralm, Steinalm, Reifling, Ramin, Wetterstein, Opponitz and Dachstein limestones versus Wetterstein Dolomites and Hauptdolomites; Began et al. 1984). Karst-fissure permeability of limestones contrasts with fissure and/or fissure-porous permeability of relatively more rigid dolomites. Outcropping dolomites prevail on $68.9 \%$, while uncovered area of limestones $\left(24.1 \mathrm{~km}^{2}\right.$, e.i., $\left.31.1 \%\right)$ is substantially smaller. This fact is reflected in a relatively low number of caves registered in the Brezovské Karpaty Mts. (Bella et al. 2007). Amidst a 700-1,100 m thick massif of Middle and Upper Triassic dolomites and limestones there is a fairly thin $(5-10 \mathrm{~m})$ horizon of sandstones and shales - the Lunz beds - which is the only impermeable formation within the Jablonica Group. It acts as a barrier as well as impermeable substratum separating individual groundwater circuits and significantly influencing their flow direction. No swallow holes - ponors - are present in the area, and groundwater is recharged purely by effective (unevaporated) precipitation.

Although superficial karstic features are seldom, several major groundwater outlets with typical karstic behaviour are present, implying underground karstification. The main drainage area is a large areal spring $1 \mathrm{~km}$ north from Dechtice $\left(\sim 425 \mathrm{~L} \cdot \mathrm{s}^{-1}\right)$, where about $30-50 \%$ of yielding groundwater is abstracted via several deep wells. The average specific runoff $9.98 \mathrm{~L} \cdot \mathrm{s}^{-1} \cdot \mathrm{km}^{-2}(315 \mathrm{~mm})$ from the outcropping Triassic carbonates in the Brezovské Karpaty Mts. does not correspond to climatic and hydrogeological settings of the area inferred from analogy with surrounding mountains. It is higher by some $3.3-3.6 \mathrm{~L} \cdot \mathrm{s}^{-1} \cdot \mathrm{km}^{-2}$. The excessive runoff can be explained by hidden inflow from the surrounding Upper Cretaceous and Neogene sedi- mentary strata formations (sandstones, siltstones, conglomerates) to carbonate structures (Malík et al. 1992). For the whole area $\left(193.25 \mathrm{~km}^{2}\right)$, the specific runoff in hydrological year 1988 was $5.74 \mathrm{~L} \cdot \mathrm{s}^{-1} \cdot \mathrm{km}^{-2}(181 \mathrm{~mm})$, which is more adequate to its position on the continent $\left(\mathrm{E} 17^{\circ} 35^{\prime} ; \mathrm{N} 48^{\circ} 30^{\prime}\right)$, the average altitude of $318.1 \mathrm{~m}$ asl and an average precipitation of $694.8 \mathrm{~mm} /$ year. However, for the vicinity of the reported springs (Vitek; Stužková; Spod javora; Tri mlynky), the value of average specific groundwater runoff is smaller, within the interval of $4.2-5.5 \mathrm{~L} \cdot \mathrm{s}^{-1} \cdot \mathrm{km}^{-2}$, as calculated from the possible extent of the recharge areas (Vítek: $3.48 \mathrm{~km}^{2}$; Stužková: $1.08 \mathrm{~km}^{2}$; Spod javora: $1.81 \mathrm{~km}^{2}$; Tri mlynky: $1.56 \mathrm{~km}^{2}$ ) and average discharge data from Tab. 1. Recharge areas of springs were delineated according to local geological and geomorphological settings and water balance results. Positions and discharges of other springs, not mentioned in this paper (as not monitored for isotopes), were also taken into account in the process of recharge areas' delineation. Underground watersheds of the discussed springs are embedded in a consistent mosaic of the Brezovské Karpaty Mts. springs' recharge areas. Altitudes of individual spring's catchments were then derived from digital elevation model with the $10 \times 10 \mathrm{~m}$ resolution. GIS MapInfo Professional 9.0 was used both for calculation of spring catchments' areas and their altitudes.

Total dissolved solids (T.D.S.) content of these relatively uncontaminated sources attains approximately 500 - $600 \mathrm{mg} \cdot \mathrm{L}^{-1}$, with $\mathrm{Ca}^{2+} \sim 92.7 \mathrm{mg} \cdot \mathrm{L}^{-1}, \mathrm{Mg}^{2+} \sim 32.7 \mathrm{mg} \cdot \mathrm{L}^{-1}$, $\mathrm{NO}_{3}^{-} \sim 5.0 \mathrm{mg} \cdot \mathrm{L}^{-1}, \mathrm{Cl}^{-} \sim 3.7 \mathrm{mg} \cdot \mathrm{L}^{-1}, \mathrm{SO}_{4}^{-} \sim 29.9 \mathrm{mg} \cdot \mathrm{L}^{-1}$ and $\mathrm{HCO}_{3}^{2-} \sim 405.2 \mathrm{mg} \cdot \mathrm{L}^{-1}$ (average values by Vrana in Malík et al. 1992). 


\section{MATERIALS AND METHODS}

Discharge and water temperature of the investigated springs were monitored on gauging once per week (each Wednesday) by an observer on small V-shaped weirs, belonging to the basic monitoring network of springs run by Slovak Hydrometeorological Institute (SHMI), and all these data are stored in its database. Spring Vítek near Chtelnica has a SHMI catalogue number of 231, No. 43 stands for spring Stužková near Jablonica; No. 251 for spring Spod javora in the part Pustá Ves of the Prašník municipality (the spring is known also under the name Šteruská); and spring Tri mlynky near Hradište pod Vrátnom has a SHMI catalogue No. 37. Data recorded by a SHMI observer, and stored in the SHMI database are plotted as solid curve on Fig. 7a. Consistent decreas- ing parts of these SHMI discharge time series, at least 8 weeks long, depicted in one synchronised plot, were used for construction of recession curves (Figs. 5 and 6). Basic characteristics of these springs are shown in Tab. 1, position of the monitored springs on the simplified geological sketch of the Brezovské Karpaty Mts. is on Fig. 2. However, in some cases discharge values reported by SHMI were not in agreement with the in situ observations. Data observed in field during sampling are plotted as circle points on Figs. 7a, 7c and 7d. In Tab. 6, discharge field observations of spring Vítek are listed instead of the SHMI values. For separation of groundwater flow components, discharge values gathered during field samplings were used.

Tab. 1: $\quad$ Basic characteristics of investigated springs in the Brezovské Karpaty Mts.

\begin{tabular}{|c|c|c|c|c|c|c|c|}
\hline site - spring & $\begin{array}{c}\text { monitored } \\
\text { since }\end{array}$ & $\begin{array}{c}\text { monitored } \\
\text { up to }\end{array}$ & $\begin{array}{l}\text { Q min. } \\
{\left[\mathrm{L} \cdot \mathrm{S}^{-1}\right]}\end{array}$ & $\begin{array}{l}\text { Q avg. } \\
{\left[\mathrm{L} \cdot \mathrm{S}^{-1}\right]}\end{array}$ & $\begin{array}{l}Q \text { max. } \\
{\left[L \cdot s^{-1}\right]}\end{array}$ & $\begin{array}{c}\mathrm{T} \min . \\
{\left[{ }^{\circ} \mathrm{C}\right]}\end{array}$ & $\begin{array}{c}\mathrm{T} \max . \\
{\left[{ }^{\circ} \mathrm{C}\right]}\end{array}$ \\
\hline Chtelnica - Vítek & 1984 & 2003 & 3.65 & 14.52 & 42.6 & 9.4 & 11.0 \\
\hline Jablonica - Stužková & $\begin{array}{l}1955 \\
1972 \\
\end{array}$ & $\begin{array}{l}1967 \\
2003 \\
\end{array}$ & 0.58 & 5.91 & 139.0 & 6.9 & 12,0 \\
\hline Prašník - Spod javora (Šteruská) & 1984 & 2003 & 2.64 & 8.86 & 20.1 & 5.2 & 13,0 \\
\hline Hradište pod Vrátnom - Tri mlynky & $\begin{array}{l}1960 \\
1984 \\
\end{array}$ & $\begin{array}{l}1966 \\
1992\end{array}$ & 0.00 & 6.97 & 14.0 & 8.0 & 13.5 \\
\hline Žriedlová dolina - Dolný & $\begin{array}{l}1957 \\
1984\end{array}$ & $\begin{array}{l}1966 \\
1992\end{array}$ & 3.30 & 5.26 & 8.4 & - & - \\
\hline
\end{tabular}

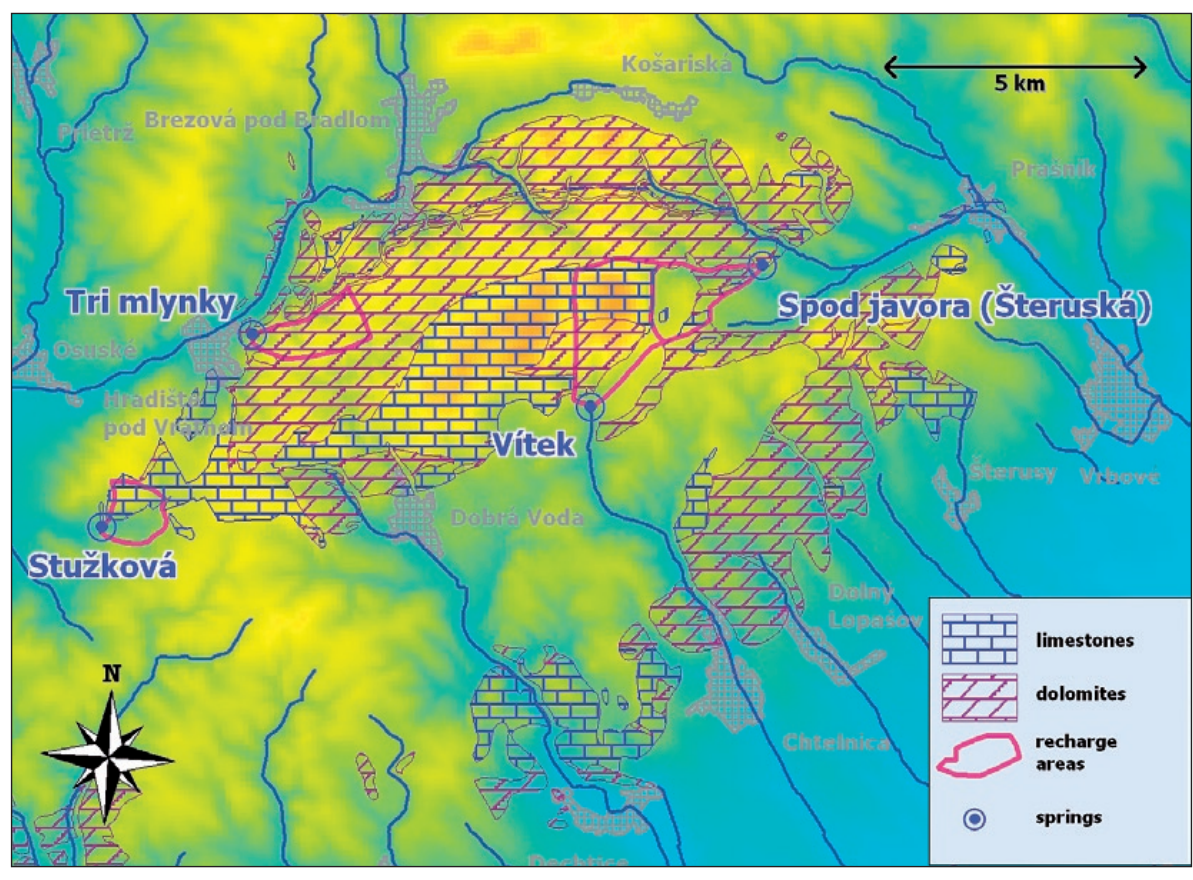

Fig. 2: Simplified geological sketch map of the Brezovské Karpaty Mts., position of the monitored springs are indicated.
Groundwater quality of four karstic springs Vítek, Stužková, Spod javora and Tri mlynky was periodically monitored in approximately 20 -days step in the period of 1987-1989. Sampling started at Nov. 19, 1987, last sample was taken on Feb. 28, 1989 and together 22 samples from each spring were taken to analyse groundwater chemistry. Nature of groundwater chemistry regime is not in the scope of view of this paper. More details can be found in the paper by Malík et al. (1992). In 15 cases from 22 mentioned, together with groundwater chemistry sampling also samples for $\delta^{18} \mathrm{O}$ analyses (in \%o vs. SMOW) were taken. Samples were 
Tab. 2: Basic results of oxygen isotope analyses - water from springs in the Brezovske Karpaty Mts.

\begin{tabular}{|l|c|c|c|c|c|c|c|c|}
\hline spring name: & \multicolumn{2}{|c|}{ Vítek } & \multicolumn{2}{c|}{ Stužková } & \multicolumn{2}{c|}{ Šteruská } & \multicolumn{2}{c|}{ Tri mlynky } \\
\hline date: & $\begin{array}{c}\delta^{18} \mathrm{O} . \\
{[\% \text { SMOW] }}\end{array}$ & $\begin{array}{c}\mathrm{T}_{\text {water }} \\
{\left[{ }^{\circ} \mathrm{C}\right]}\end{array}$ & $\begin{array}{c}\delta^{18} \mathrm{O} . \\
{[\% \circ \mathrm{SMOW}]}\end{array}$ & $\begin{array}{c}\mathrm{T}_{\text {water }} \\
{\left[{ }^{[} \mathrm{C}\right]}\end{array}$ & $\begin{array}{c}\delta^{18} \mathrm{O} . \\
{[\% \circ \mathrm{SMOW}]}\end{array}$ & $\begin{array}{c}\mathrm{T}_{\text {water }} \\
{\left[{ }^{\circ} \mathrm{C}\right]}\end{array}$ & $\begin{array}{c}\delta^{18} \mathrm{O} . \\
{\left[\% \mathrm{SMOW}^{\circ} \mathrm{SMOW}\right.}\end{array}$ & $\begin{array}{c}\mathrm{T}_{\text {water }} \\
{\left[{ }^{\circ} \mathrm{C}\right]}\end{array}$ \\
\hline 11.01 .1988 & -11.16 & 10.0 & -10.79 & 10.8 & -11.10 & 8.5 & -11.02 & 10.8 \\
\hline 28.01 .1988 & -11.15 & 10.2 & -10.93 & 10.5 & -10.88 & 8.6 & -11.01 & 10.8 \\
\hline 02.03 .1988 & -11.34 & 10.4 & -11.03 & 10.4 & -11.29 & 8.2 & -11.10 & 10.4 \\
\hline 16.03 .1988 & -11.24 & 10.2 & -10.96 & 10.2 & -11.15 & 8.2 & -10.98 & 11.0 \\
\hline 05.04 .1988 & -11.36 & 11.0 & -11.12 & 10.5 & -11.27 & 8.0 & -11.12 & 10.5 \\
\hline 26.04 .1988 & -11.24 & 10.0 & -11.13 & 11.0 & -11.10 & 9.5 & -11.12 & 10.0 \\
\hline 25.05 .1988 & -11.34 & 10.0 & -10.94 & 11.0 & -11.19 & 9.8 & -11.03 & 11.7 \\
\hline 07.06 .1988 & -11.42 & 9.8 & -11.11 & 10.2 & -11.32 & 10.5 & -11.18 & 11.2 \\
\hline 30.06 .1988 & -11.41 & 10.5 & -10.95 & 10.9 & -11.26 & 10.0 & -11.02 & 11.5 \\
\hline 25.07 .1988 & -11.26 & 10.4 & -11.21 & 10.8 & -11.08 & 10.5 & -10.90 & 11.4 \\
\hline 06.09 .1988 & -11.14 & 10.5 & -11.05 & 10.8 & -11.18 & 10.4 & -11.10 & 11.4 \\
\hline 26.09 .1988 & -11.41 & 10.4 & -11.01 & 10.6 & -11.23 & 10.6 & -11.10 & 11.1 \\
\hline 17.10 .1988 & -11.34 & 10.6 & -10.91 & 10.4 & -11.18 & 10.6 & -10.97 & 11.1 \\
\hline 08.11 .1988 & -11.10 & 10.2 & -11.26 & 10.6 & -11.24 & 9.5 & -11.07 & 10.6 \\
\hline 03.01 .1989 & -11.62 & 10.2 & -11.14 & 10.5 & -11.58 & 8.5 & -11.27 & 10.5 \\
\hline
\end{tabular}

taken into $0.05 \mathrm{~L}$ glass bottles with watertight plastic stopper, and after sampling filtered and stored in a fridge in a temperature of $5^{\circ} \mathrm{C}$.

Oxygen isotope data were obtained by measurements in the laboratory of Isotope Geology Dpt., State Geological Institute of Dionýz Štúr in Bratislava, Slovakia, by standard $\mathrm{H}_{2} \mathrm{O}-\mathrm{CO}_{2}$ equilibrium method (Epstein \& Mayeda 1953) using the Finnigan MAT 250 instrument, with the accuracy of $\delta^{18} \mathrm{O}$ better than $\pm 0.05 \%$ o
(Rúčka 1998). Results are shown in Tab. 2. As shown of Fig. 2, spring Tri mlynky is bound to dominantly dolomitic aquifer, spring Stužková to dominantly limestone aquifer and within the recharge areas of springs Vítek and Spod javora, both limestones and dolomites are present. Three of these springs (apart from Stužková) were exploited as drinking water sources of regional importance.

\section{OVERVIEW OF $\delta^{18}$ O RESULTS}

Results of the monitoring of isotope composition of water, shown in Tab. 2, are relatively similar for all the springs. All the values vary from $-11.62 \%$ to $-10.79 \%$, with the overall average value of $-11.15 \%$. The differences between individual springs seem to be dependent on relative altitudinal position of springs' recharge areas, not too enhanced in the flat hills of the Brezovské Karpaty Mts. The position of springs is very similar and varies from 250 to $275 \mathrm{~m}$ asl (see Tab. 3). However, altitude of recharge area is slightly more different and a negative correlation effect with the altitude can be found, with the gradient of $-0.15 \%$ of $\delta^{18} \mathrm{O}$ values with each $100 \mathrm{~m}$ of altitude (correlation coefficient - 0.70). Malík et al. (1993) reported some $100 \mathrm{~m}$ altitude change with $0.1 \%$ of $\delta^{18} \mathrm{O}$ difference for karst springs in the Velká Fatra Mts. (Slovakia).
In the detailed time plot (Fig. 3), the differences in $\delta^{18} \mathrm{O}$ values are evident, as changing with time/discharge of individual springs. The relative difference of $\delta^{18} \mathrm{O}$ values between individual springs seem to be steady, while they all vary in time with less or more similar behaviour. However, the differences in their discharges are not the same. As a first interpretation step, $\delta^{18} \mathrm{O}$ values were plotted against discharges (Fig. 4), with slightly contradictory results for different springs. This was previously supposed as consequence of differences between groundwater circulation in dolomites vs. limestones (compare Tri mlynky - dolomitic and Vítek - limestone recharge area on Fig. 4). In the dolomitic aquifer, the oxygen isotopes in water were heavier with increasing discharge (Hradište pod Vrátnom - Tri mlynky spring), while in the more karstified limestone 
Tab. 3: Basic statistic data on $\delta^{18} \mathrm{O}$ values and temperature - springs in the Brezovské Karpaty Mts.

\begin{tabular}{|l|c|c|c|c|c|c|c|c|}
\hline spring name: & \multicolumn{2}{|c|}{ Vítek } & \multicolumn{2}{c|}{ Stužková } & \multicolumn{2}{c|}{ Spod javora (Šteruská) } & \multicolumn{2}{c|}{ Tri mlynky } \\
\hline spring's altitude & \multicolumn{2}{|c|}{$275 \mathrm{~m}$} & \multicolumn{2}{c|}{$250 \mathrm{~m}$} & \multicolumn{2}{c|}{$250 \mathrm{~m}$} & \multicolumn{2}{c|}{$348 \mathrm{~m}$} \\
\hline altitude of recharge area & \multicolumn{2}{|c|}{$448 \mathrm{~m}$} & \multicolumn{2}{c|}{$313 \mathrm{~m}$} & \multicolumn{2}{c|}{$393 \mathrm{~m}$} \\
\hline parameter: & $\begin{array}{c}\delta^{18} \mathrm{O} . \\
{[\mathrm{SMOW}]}\end{array}$ & $\begin{array}{c}\mathrm{T}_{\text {water }} \\
{\left[{ }^{\circ} \mathrm{C}\right]}\end{array}$ & $\begin{array}{c}\delta^{18} \mathrm{O} . \\
{[\mathrm{SMOW}]}\end{array}$ & $\begin{array}{c}\mathrm{T}_{\text {water }} \\
{\left[{ }^{\circ} \mathrm{C}\right]}\end{array}$ & $\begin{array}{c}\delta^{18} \mathrm{O} . \\
{[\mathrm{SMOW}]}\end{array}$ & $\begin{array}{c}\mathrm{T}_{\text {water }} \\
{\left[{ }^{\circ} \mathrm{C}\right]}\end{array}$ & $\begin{array}{c}\delta^{18} \mathrm{O} . \\
{[\mathrm{SMOW}]}\end{array}$ & $\begin{array}{c}\mathrm{T}_{\text {water }} \\
{\left[{ }^{\circ} \mathrm{C}\right]}\end{array}$ \\
\hline minimum & -11.62 & 9.8 & -11.26 & 10.2 & -11.58 & 8.0 & -11.27 & 10.0 \\
\hline maximum & -11.10 & 11.0 & -10.79 & 11.0 & -10.88 & 10.6 & -10.90 & 11.7 \\
\hline average & -11.301 & 10.29 & -11.035 & 10.61 & -11.201 & 9.43 & -11.065 & 10.93 \\
\hline median & -11.34 & 10.2 & -11.03 & 10.6 & -11.19 & 9.5 & -11.07 & 11.0 \\
\hline standard deviation & 0.137 & 0.30 & 0.126 & 0.26 & 0.151 & 1.00 & 0.092 & 0.47 \\
\hline
\end{tabular}

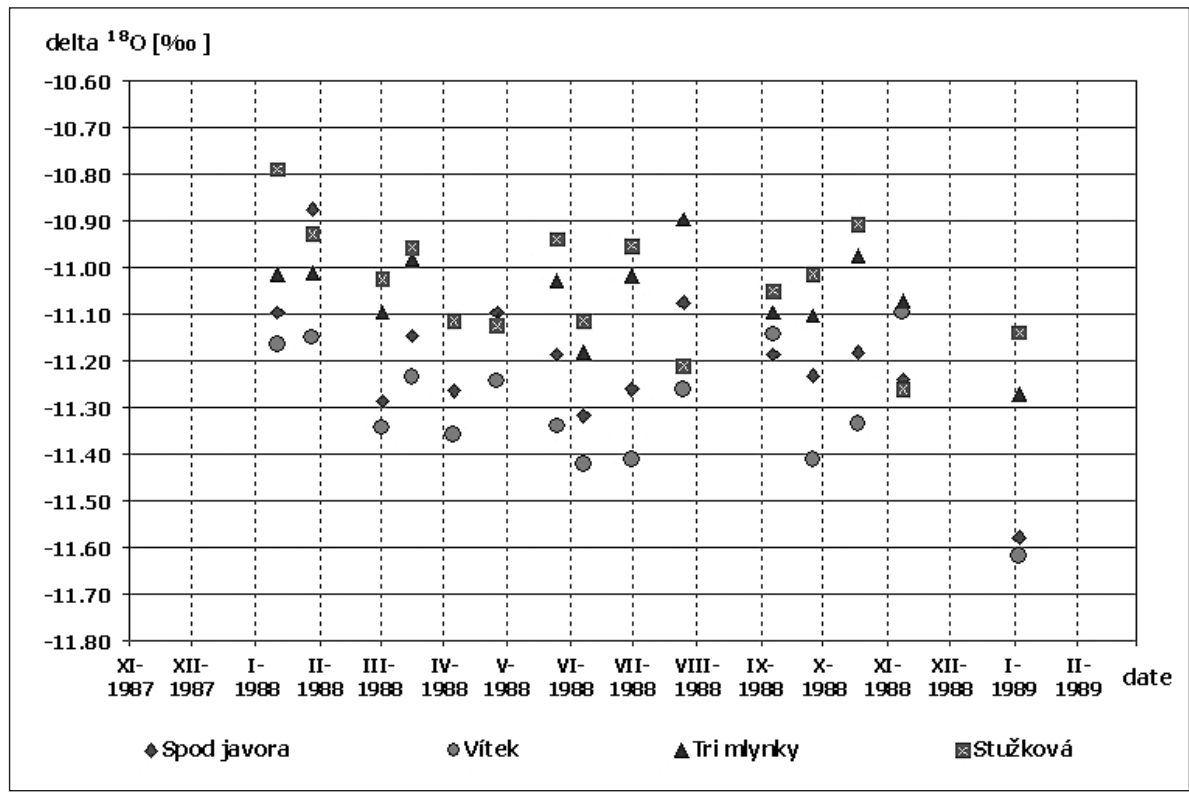

Fig. 3: Time plot of $\delta^{18} \mathrm{O}$ values - four karstic springs in the Brezovské Karpaty Mts. more depleted in ${ }^{18} \mathrm{O}$. The observed facts were not so outright (Fig. 4), but at the time of the investigation (1987-1989) there were not too many possibilities for advanced interpretations.

Unsteady discharge throughout the year, steep peaks and long-lasting steady outflow within dry periods, typical for karstic springs, were found in "Vítek", "Stužková" and "Spod javora" springs, while "Tri mlynky" showed a very steady outflow. Although Fig. 4 implies some relation between groundwater quantity and oxygen isotope composition, more sophisticated understanding in the recharge area of spring Vitek near Chtelnica, the increased volume of discharged groundwater was should come from the apprehension of quantitative behaviour of springs - differentiation to flow components.
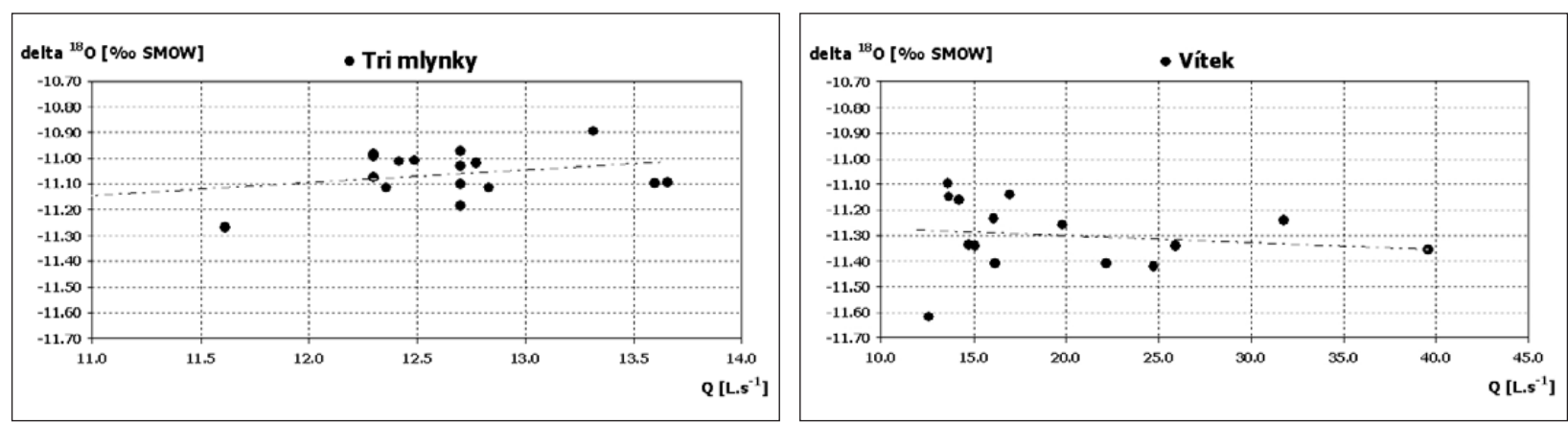

Fig. 4: Values of $\delta^{18} \mathrm{O}(\mathrm{SMOW})$ plotted against discharges of monitored springs Tri mlynky and Vitek. 


\section{RECESSION CURVES ANALYSES}

Although the principles of hydrograph analyses are developed for more than a century (Boussinesq 1877; Maillet 1905; Horton 1933; Barnes 1939; Cooper \& Rorabaugh 1963; Kullman 1990; Padilla et al. 1994; Griffiths \& Clausen 1997; Kovács 2003), only computerised algorithms enabled its proper use for distinguishing of different elements in groundwater mixtures (Goldscheider \& Drew 2007). In this study, we are using simple exponential description $-Q_{t}=Q_{0} \cdot e^{-\alpha \cdot t}$ - set of laminar subregimes as defined by Forkasiewicz and Paloc (1967), and a linear turbulent model for flow supposed to be in karstic channels $-Q_{t}=Q_{0} \cdot(1-\beta \cdot t)-$ as described by Kullman (1983). Several, both laminar and turbulent, subregimes may exist in one aquifer, and its discharge can be described by superposition of several appropriate equations (Kullman 1990). Hydrograph recession curves can be used for analysis of type and properties of a karstic aquifer (Kullman 2000), as well as for estimation of regional karstification degree and groundwater sensitivity to pollution (Malík
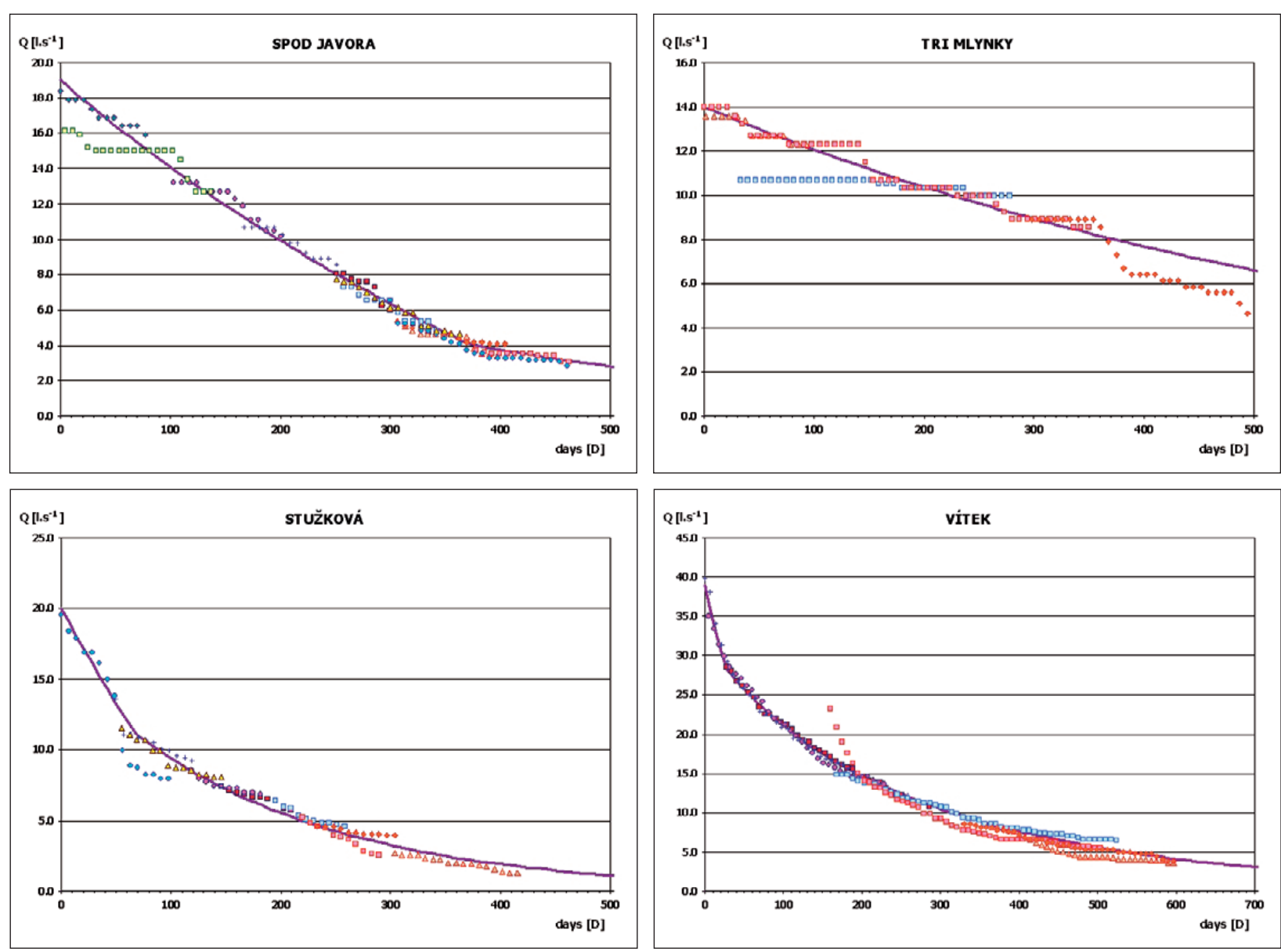

Fig. 5: Plots of typical recession curves of investigated springs in the Brezovské Karpaty Mts., evaluated on the base of assemblage individual recession curves from dry periods. 
Tab. 4: Recession curves parameters of investigated springs in the Brezovské Karpaty Mts.

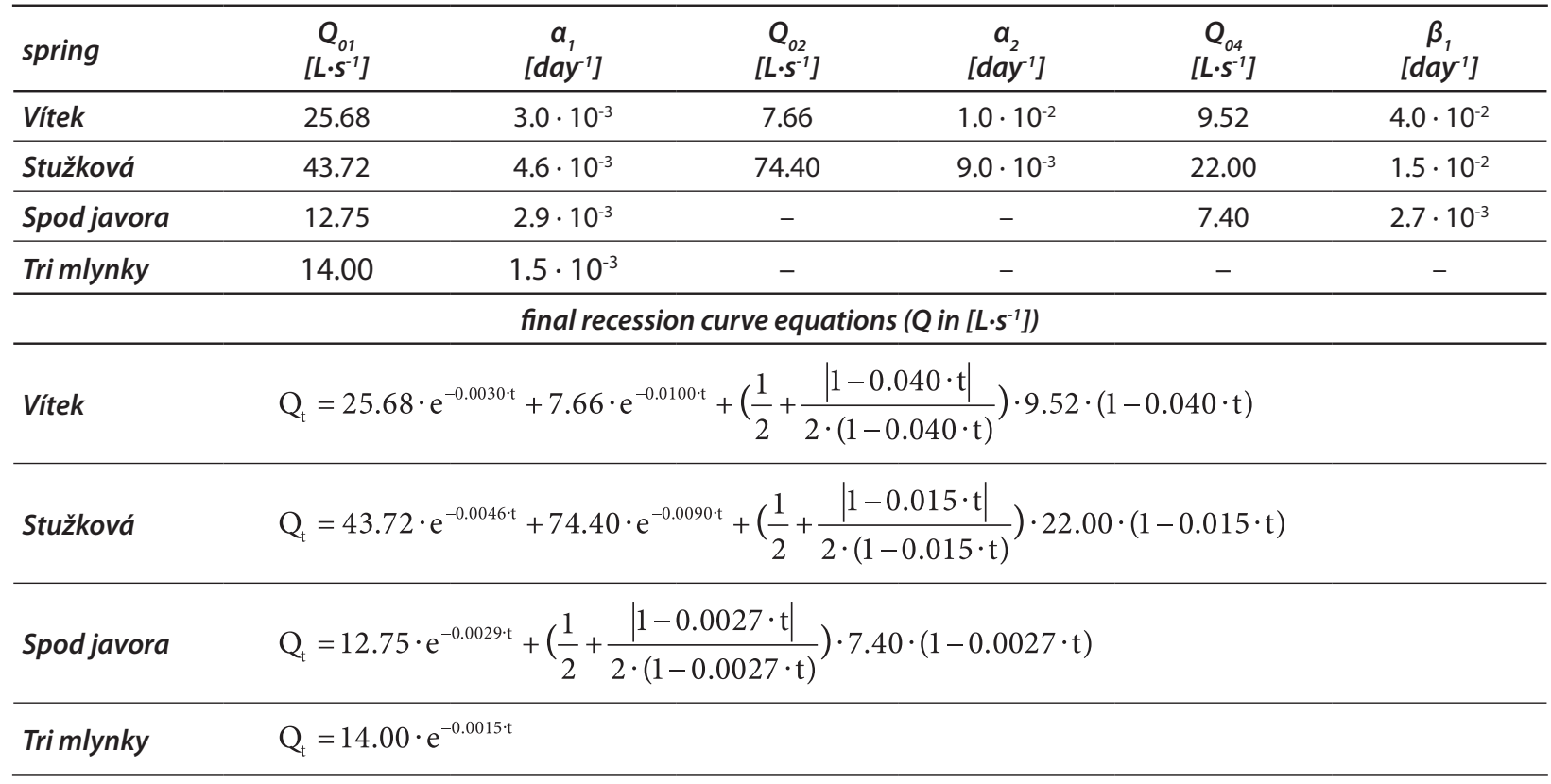
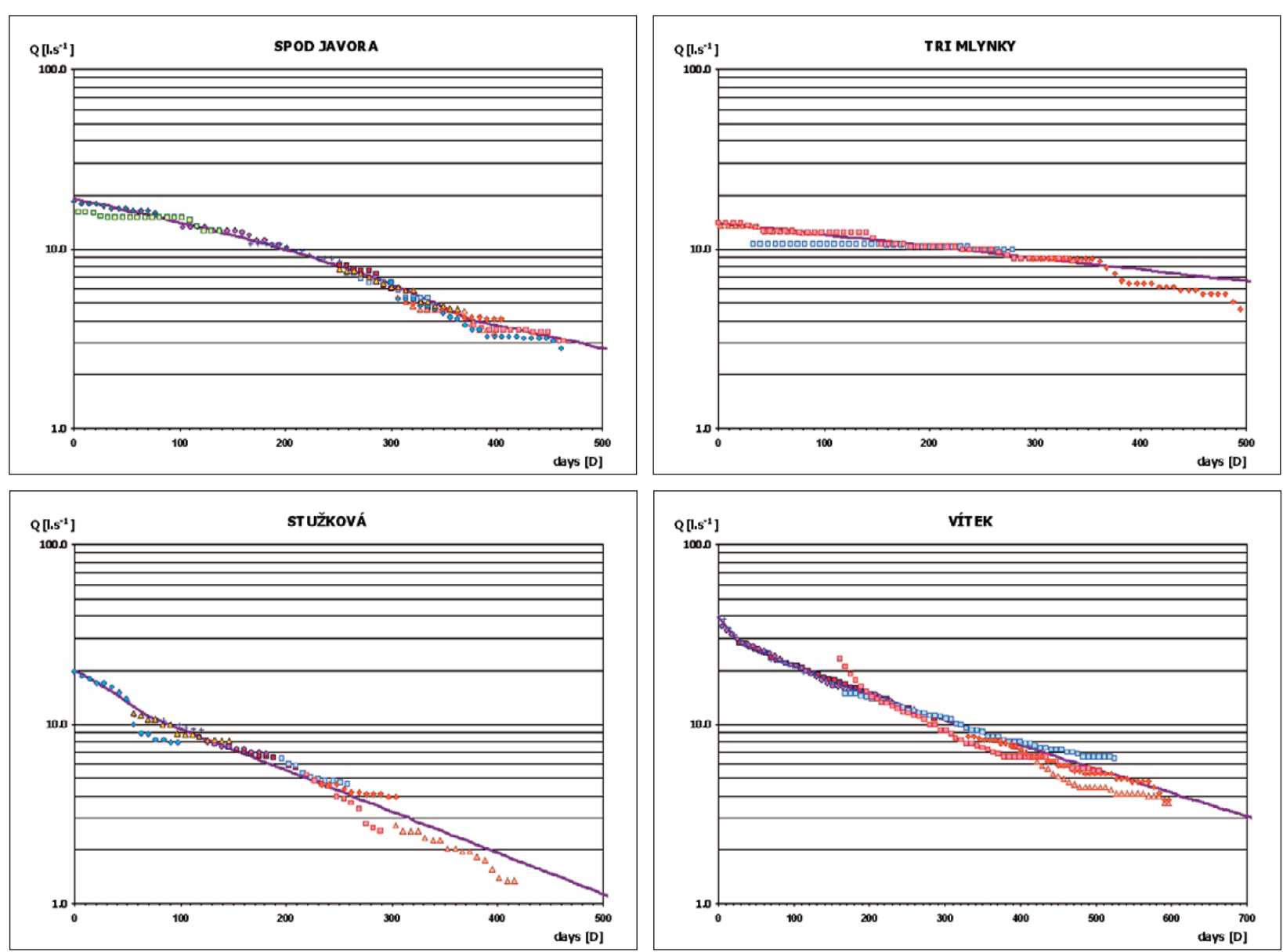

Fig. 6: Logarithmic plots of typical recession curves of investigated springs in the Brezovské Karpaty Mts., evaluated on the base of assemblage individual recession curves from dry periods. 
are determined by proper hydrograph analyses in the way that their total equals or is higher than the maximum spring's discharge $Q_{\max }$ :

$Q_{\max } \leq \sum_{1}^{m} Q_{0 m}+\sum_{4}^{n} Q_{0 n}$

Proper hydrograph analyses of the complete discharge data time series, synchronised according to the decreasing discharge time sequentiality, shown in one plot, can yields then $\alpha_{k}$ and $\beta_{l}$ values (see Figs. 5 and 6). If it is not possible to construct a recession equation with $Q_{\max }$ equal to recorded maximum discharge from available consistent time series with decreasing discharge, representative starting discharge values of individual subregimes $Q_{0 n}$ and $Q_{0 m}$ for recession equation should be extrapolated to achieve this condition.

All the SHMI discharge time series of four monitored springs, reported in Tab. 1, were processed for the construction of recession curves (points of different colour and shape in Figs. 5 and 6). All consistent decreasing parts of the discharge time series, longer than 8 weeks (8 discharge values), were depicted in one synchronised plot, and a best fitting recession curve shape was assigned.

In Tab. 4, these curves are described as a superposition of several exponential and linear equations, both as individual parameters and resulting equations. For springs Vítek and Stužková, two exponential (laminar) and one linear (turbulent) flow components were found. One laminar and one turbulent flow component was linked to the Spod javora spring, while Tri mlynky spring seems to have only one laminar flow component. In Figs. 5 and 6 , a thick violet line, described by the aforementioned equation, is supposed to represent the standard recession.

\section{HYDROGRAPH SEPARATION INTO SUBREGIMES}

After all the subregimes of an aquifer or spring were explicitly defined, the reverse method of hydrograph separation can be implemented for determination of e.g., groundwater amounts discharged in individual subregimes. The main principle for developing hydrograph separation tool, based on solution of sequence of equations, is a presumption that the discharge from an aquifer depends on the level of its saturation by groundwater, and that the same discharge reflects the same groundwater saturation (piezometric) level. Each spring is described by unique, constant values of $Q_{0 n}, Q_{0 m}$, starting discharges and $\alpha_{k}$ and $\beta_{l}$ recession coefficients for each subregime. Having the equation with these fixed parameters, every discharge value from the spring's dataset $Q_{t}$ is given just by a representative time $t$, theoretical elapsed time from the overall maximum discharge value $Q_{\max }$. In other words, theoretical elapsed time $t$ from the total maximum spring's discharge $Q_{\max }$ can determinate every discharge value, and can be calculated by solving the recession equation.

The total spring's discharge also has to be the sum of partial discharges of individual subregimes participating (in the moment of measurement $t$ ) on the spring's discharge. Theoretical elapsed time $t$ should be the same for all flow components - subregimes. If we can solve the spring's recession equation for the discharged value $Q_{t}$ and obtain the theoretical elapsed time $t$ from the total discharge maximum $Q_{\max }$, we can also easily calculate the partial discharges $Q_{t m}$ or $Q_{t n}$ of different flow subregimes using the same $t$ value in their partial equations. Subsequently, proportional amounts of different discharging subregimes can be calculated, both for the whole period and for every moment of evaluated period. As the exponential equation has no analytical solution,

Tab. 5: Volume of groundwater discharged in individual subregimes in the period of Nov. 01, 1987-Feb. $28,1989$.

\begin{tabular}{|c|c|c|c|c|c|}
\hline spring & $\begin{array}{c}\text { average. } \\
\text { discharge. } \\
{\left[\mathrm{L} \cdot \mathrm{S}^{-1}\right]}\end{array}$ & $\begin{array}{c}\text { total. } \\
\text { discharged. } \\
\text { volume. } \\
\text { [mil. } \mathrm{m}^{3} \text { ] } \\
\end{array}$ & $\begin{array}{c}\text { volume in. } \\
1^{\text {st }} \text { laminar } \\
\text { subregime. } \\
\left.\text { [mil. } \mathrm{m}^{3}\right]\end{array}$ & $\begin{array}{l}\text { volume in. } \\
2^{\text {nd }} \text { laminar } \\
\text { subregime. } \\
\left.\text { [mil. } \mathrm{m}^{3}\right]\end{array}$ & $\begin{array}{c}\text { volume in } \\
\text { turbulent } \\
\text { subregime. } \\
\text { [mil. } \mathrm{m}^{3} \text { ] }\end{array}$ \\
\hline Vítek & 19.54 & 11.818 & 10.103 & 1.465 & 0.250 \\
\hline Stužková & 10.57 & 6.393 & 4.696 & 1.697 & - \\
\hline Spod javora (Šteruská) & 12.27 & 7.418 & 4.877 & - & 2.541 \\
\hline Tri mlynky & 12.11 & 7.322 & 7.322 & - & - \\
\hline
\end{tabular}



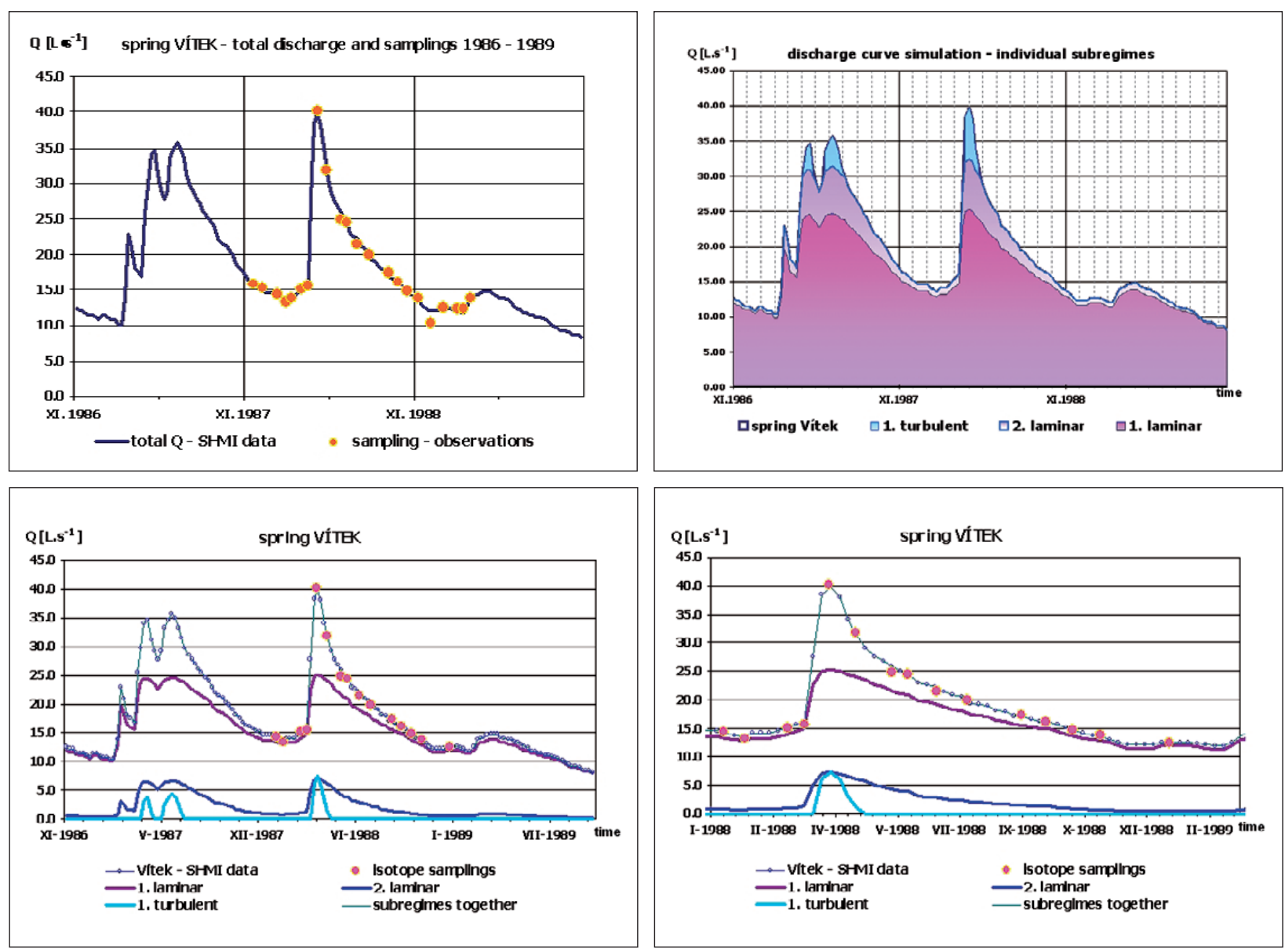

Fig. 7: Vitek spring (near Chtelnica) - a) discharge and samplings in hydrological years 1987, 1988 and 1989; b) hydrograph separation into 3 different subregimes; c) samplings and discharges in different subregimes in hydrological years 1987-1989; d) detailed samplings and discharges in different subregimes in the period 1988-1989.

the set of pre-described equations for each real discharge value has to be solved by iteration process to obtain partial discharges for each subregime. In the iteration process, the two starting time inputs were usually set to be 0 and $1 / \alpha_{1}$. Ten iteration procedures were sufficient to give result within the discharge reading accuracy. To control the calculation, the total discharge has to be the sum of these partial discharges.
In this way, volumes of groundwater discharged in individual flow components - subregimes were calculated for the period of Nov. 01, 1987 - Feb. 28, 1989 for four karstic springs - Vítek, Stužková, Spod javora and Tri mlynky (Tab. 5). Hydrograph separation example for spring Vítek into three individual subregimes $\left(1^{\text {st }}\right.$ laminar, $2^{\text {nd }}$ laminar, turbulent) on Figs. 7 b, c and d also show the flow components as lines of different colour.

\section{RESULTS: QUALITATIVE DIFFERENCES BETWEEN HYDROGRAPH SUBREGIMES}

The change of groundwater properties of individual springs in time (Fig. 3, Tab. 2) can be linked to mixing of groundwater of different origin. One of the explanations of the temporal $\delta^{18} \mathrm{O}(\mathrm{SMOW})$ values change (and other qualitative groundwater properties, of course) is different proportional representation of individual subregimes in the final mixture. If we assume the slowest groundwater circulation to be present in smallest fissures ( $1^{\text {st }}$ laminar subregime), the groundwater present in fissures with higher aperture to be exfiltrated in the $2^{\text {nd }}$ laminar subregime, and the groundwater circulating in open karstic conduits to be represented by turbulent flow subregimes, 
we can make an attempt to interpret and "reconstruct" the groundwater composition of $100 \%$ subregimes.

In Tab. 6, proportional representation of individual subregimes discharge on the total discharge (in \%), together with absolute values (in $\mathrm{L} \cdot \mathrm{s}^{-1}$ ) are listed for the spring Vítek. Similar calculation, using equations' parameters from Tab. 4, was performed to obtain subregime discharges for each spring. Based on possible impact proportional representation a subregimes (in \%) on the final mixture $\delta^{18} \mathrm{O}$ value (\% SMOW), a forecast for $100 \%$ representation of a subregime can be calculated by simple statistics. The same processing was performed with groundwater temperature values (data shown in Tab. 2 for all springs, and Tab. 6 for spring Vítek). Results for $100 \%$ representation forecast both for $\delta^{18} \mathrm{O}$ and groundwater temperature in the $1^{\text {st }}$ laminar, $2^{\text {nd }}$ laminar and turbulent subregimes are listed in Tab. 7.

In comparison with Tab. 3, and also with its last two columns, the results for $\delta^{18} \mathrm{O}$ values in $100 \%$ representation forecast in the Tab. 7 for the $1^{\text {st }}$ laminar subregime are very similar to evaluation without subregimes. The reason is the overall nature of the springs (dolomitic aquifers), as well as character of the recession curves with dominating $1^{\text {st }}$ laminar subregime.

However, results for $2^{\text {nd }}$ laminar and turbulent subregimes seem to be contradictory in both cases. Groundwater contained in the macrofracture system ( $2^{\text {nd }}$ laminar subregime) of the Vitek spring is both more depleted in $\delta^{18} \mathrm{O}$, in comparison to the $1^{\text {st }}$ laminar "baseflow". The $2^{\text {nd }}$ laminar subregime in Stužková spring keeps approximately the same value of $\delta^{18} \mathrm{O}$, but also points to colder circulating groundwater. The only two turbulent subregimes (springs Vítek and Spod javora) seem to be unrealistically exaggerated in water temperatures (calculated data). While in the case of spring Vítek, turbulent flow component was present only in two samplings, in the case of Spod javora spring the turbulent flow component was constantly present - see the different character of this spring's depletion on Figs. 5 and 6. Very probably, the reason for the very unrealistic temperature of the pure $(100 \%)$ turbulent flow component in spring Spod javora is caused by the poor quality of discharge data, we assume due to unreliability of local observer. The data measured during sampling were always different from the reported ones (from $-22 \%$ to $+17 \%$ in comparison to SHMI database). Unusually very low value of the $\beta_{1}$ member in comparison to other springs probably confirms this suspicion. Unfortunately, SHMI dataset discharges were the only data that could be processed for hydrograph analysis. Spod javora results are therefore only of illustrative value of applied separation techniques and do not have any practical meaning for the description of processes within the aquifer. Spring Vítek does not show such behaviour, anyhow - the "turbulent" $\delta^{18} \mathrm{O}$ values there are very similar to those in the $2^{\text {nd }}$ laminar subregime. Obtained results are based only on sparsely populated datasets (two samples with the presence of turbulent subregime) and manual discharge records. Still, such approach may represent a perspective method for further development and interpretations of automatically recorded and sampled data collections.

Tab. 6: Spring Vitek - total discharge and discharges calculated for individual subregimes, with their proportional representation on the total discharge, in the sampling days (Tab. 2; shown on Fig. 7) for $\delta^{18} \mathrm{O}$.

\begin{tabular}{|c|c|c|c|c|c|c|c|c|c|}
\hline date & $\begin{array}{l}\mathbf{Q}_{\text {TOTAL }} \\
{\left[\mathrm{L} \cdot \mathrm{S}^{-1}\right]}\end{array}$ & $\begin{array}{c}\mathbf{Q}_{\text {laminar-1 }} \\
{\left[\mathrm{L} \cdot \mathrm{S}^{-1}\right]}\end{array}$ & $\begin{array}{c}\mathbf{Q}_{\text {laminar-2 }} \\
{\left[\mathrm{L} \cdot \mathrm{S}^{-1}\right]}\end{array}$ & $\begin{array}{c}\mathbf{Q}_{\text {turbulent }} \\
{\left[\mathrm{L} \cdot \mathrm{S}^{-1}\right]}\end{array}$ & $\begin{array}{c}\mathbf{Q}_{\text {laminar-1 }} \\
{[\%]}\end{array}$ & $\begin{array}{c}\mathbf{Q}_{\text {laminar-2 }} \\
{[\%]}\end{array}$ & $\begin{array}{c}Q_{\text {turbulent }} \\
{[\%]}\end{array}$ & $\begin{array}{c}\delta^{18} \mathrm{O} \\
{[\mathrm{SMOW}]}\end{array}$ & $\begin{array}{l}\mathrm{T}_{\text {water }} \\
{\left[{ }^{\circ} \mathrm{C}\right]}\end{array}$ \\
\hline 11.01 .1988 & 14.30 & 13.42 & 0.88 & 0.00 & $93.8 \%$ & $6.2 \%$ & $0.0 \%$ & -11.16 & 10.0 \\
\hline 28.01 .1988 & 13.30 & 12.59 & 0.71 & 0.00 & $94.7 \%$ & $5.3 \%$ & $0.0 \%$ & -11.15 & 10.2 \\
\hline 02.03 .1988 & 15.10 & 14.07 & 1.03 & 0.00 & $93.2 \%$ & $6.8 \%$ & $0.0 \%$ & -11.34 & 10.4 \\
\hline 16.03.1988 & 15.60 & 14.47 & 1.13 & 0.00 & $92.8 \%$ & $7.2 \%$ & $0.0 \%$ & -11.24 & 10.2 \\
\hline 05.04 .1988 & 40.20 & 25.30 & 7.29 & 7.61 & $62.9 \%$ & $18.1 \%$ & $18.9 \%$ & -11.36 & 11.0 \\
\hline 26.04 .1988 & 31.80 & 24.11 & 6.20 & 1.49 & $75.8 \%$ & $19.5 \%$ & $4.7 \%$ & -11.24 & 10.0 \\
\hline 25.05 .1988 & 24.90 & 20.99 & 3.91 & 0.00 & $84.3 \%$ & $15.7 \%$ & $0.0 \%$ & -11.34 & 10.0 \\
\hline 07.06 .1988 & 24.50 & 20.74 & 3.76 & 0.00 & $84.7 \%$ & $15.3 \%$ & $0.0 \%$ & -11.42 & 9.8 \\
\hline 30.06 .1988 & 21.50 & 18.80 & 2.70 & 0.00 & $87.4 \%$ & $12.6 \%$ & $0.0 \%$ & -11.41 & 10.5 \\
\hline 25.07.1988 & 19.90 & 17.69 & 2.21 & 0.00 & $88.9 \%$ & $11.1 \%$ & $0.0 \%$ & -11.26 & 10.4 \\
\hline 06.09.1988 & 17.40 & 15.86 & 1.54 & 0.00 & $91.2 \%$ & $8.8 \%$ & $0.0 \%$ & -11.14 & 10.5 \\
\hline 26.09.1988 & 16.10 & 14.86 & 1.24 & 0.00 & $92.3 \%$ & $7.7 \%$ & $0.0 \%$ & -11.41 & 10.4 \\
\hline 17.10.1988 & 14.80 & 13.83 & 0.97 & 0.00 & $93.4 \%$ & $6.6 \%$ & $0.0 \%$ & -11.34 & 10.6 \\
\hline 08.11 .1988 & 13.80 & 13.01 & 0.79 & 0.00 & $94.3 \%$ & $5.7 \%$ & $0.0 \%$ & -11.10 & 10.2 \\
\hline 03.01.1989 & 12.60 & 11.99 & 0.61 & 0.00 & $95.2 \%$ & $4.8 \%$ & $0.0 \%$ & -11.62 & 10.2 \\
\hline
\end{tabular}


Tab. 7: $1^{\text {st }}$ laminar, $2^{\text {nd }}$ laminar and turbulent subregimes in individual springs' discharge: results of the 100\% representation forecast for groundwater $\delta^{18} \mathrm{O}$ and temperature values.

\begin{tabular}{|c|c|c|c|c|c|c|c|c|c|}
\hline \multirow[b]{2}{*}{ spring } & \multirow{2}{*}{$\begin{array}{c}\text { recharge } \\
\text { area } \\
\text { altitude } \\
\text { [m] }\end{array}$} & \multicolumn{2}{|c|}{$1^{\text {st }}$ laminar } & \multicolumn{2}{|c|}{$2^{\text {nd }}$ laminar } & \multicolumn{2}{|c|}{ turbulent } & \multicolumn{2}{|c|}{ without subregimes } \\
\hline & & $\begin{array}{c}\delta^{18} \mathrm{O} \\
\text { [SMOW] }\end{array}$ & $\begin{array}{l}\mathrm{T}_{\text {water }} \\
{\left[{ }^{\circ} \mathrm{C}\right]}\end{array}$ & $\begin{array}{c}\delta^{18} \mathrm{O} \\
\text { [SMOW] }\end{array}$ & $\begin{array}{l}\mathrm{T}_{\text {water }} \\
{\left[{ }^{\circ} \mathrm{C}\right]}\end{array}$ & $\begin{array}{c}\delta^{18} \mathrm{O} \\
\text { [SMOW] }\end{array}$ & $\begin{array}{l}\mathrm{T}_{\text {water }} \\
{\left[{ }^{\circ} \mathrm{C}\right]}\end{array}$ & $\begin{array}{c}\delta^{18} \mathrm{O} \\
{[\mathrm{SMOW}]}\end{array}$ & $\begin{array}{l}\mathrm{T}_{\text {water }} \\
{\left[{ }^{\circ} \mathrm{C}\right]}\end{array}$ \\
\hline Vítek & 448 & -11.28 & 10.16 & -11.65 & 10.32 & -11.53 & 13.74 & -11.30 & 10.29 \\
\hline Stužková & 313 & -11.07 & 11.21 & -10.90 & 8.42 & - & - & -11.04 & 10.61 \\
\hline Spod javora & 348 & -14.45 & -38.21 & - & - & -5.24 & 96.76 & -11.20 & 9.43 \\
\hline Tri mlynky & 393 & -11.07 & 10.93 & - & - & - & - & -11.07 & 10.93 \\
\hline minimum & & -14.45 & -38.21 & -11.65 & 8.42 & -11.53 & 13.74 & -11.30 & 9.43 \\
\hline maximum & & -11.07 & 11.21 & -10.90 & 10.32 & -5.24 & 96.76 & -11.04 & 10.93 \\
\hline average & & -11.97 & -1.48 & -11.28 & 9.37 & -8.38 & 55.25 & -11.15 & 10.32 \\
\hline median & & -11.17 & 10.55 & -11.28 & 9.37 & -8.38 & 55.25 & -11.13 & 10.45 \\
\hline standard deviation & & 1.66 & 24.50 & & & & & 0.12 & 0.65 \\
\hline
\end{tabular}

\section{GROUNDWATER DATA AND IAEA GNIP}

The International Atomic Energy Agency (IAEA), in cooperation with the World Meteorological Organization (WMO), is conducting a worldwide survey of oxygen and hydrogen isotope content in precipitation - the Global Network of Isotopes in Precipitation (GNIP). This programme is operating since 1961, and basic isotope data for the use of environmental isotopes in hydrological investigations are provided for free use within the scope of water resources inventory, planning and development (IAEA/WMO 2006) on the web page http://isohis.iaea.org. Precipitation at the WMO meteorological station in Vienna - Höhe Warte is one of the stations with longest record of (not only) oxygen isotope content in precipitation. Its altitude is $203 \mathrm{~m}$ asl and the mean annual precipitation of $>150$ years of observations is $643 \mathrm{~mm}$. Its direct distance to the investigated area of Brezovské Karpaty Mts. is not more than $95 \mathrm{~km}$. On the two stations within the investigated region, similar values of annual precipitation were reported: Brezová pod Bradlom (290 m asl) - 677 mm; Dobrá Voda (257 m asl) - $672 \mathrm{~mm}$. Resulting very similar climatic conditions in the investigated area gave us a chance to use the extensive datasets from Vienna - Höhe Warte GNIP station to look on processes of groundwater recharge from the $\delta^{18} \mathrm{O}$ point of view.

The average yearly rainfall value and $\delta^{18} \mathrm{O}$ measurements in springs can be considered as good descriptors of climatic variations and can be used to estimate the recharge area and the infiltration coefficient (Binet et al. 2006). Values of $\delta^{18} \mathrm{O}$ in precipitation on the Vienna - Höhe Warte GNIP station during the period of 1961-
1987, prior to our sampling on springs, were characterised by a simple average value of $-9.38 \%$ (vs. SMOW) and weighted average (with precipitation volume as weighting factor) of $-9.57 \%$. The second (weighted) value is shown also on Fig. 8 (using solid horizontal black line, marked as Höhe Warte 1961-1987 AVG). Weighted value of $\delta^{18} \mathrm{O}$ for the period 1988-1989 (period of sampling, marked as Höhe Warte 1988-1989 AVG by dashed horizontal black line) was $-10.58 \%$, i.e., lighter by $1.02 \%$ than in the longer previous period. The values measured on our springs (various points on Fig. 8) were even more negative: the whole dataset was ranging from $-11.58 \%$ to $-10.79 \%$ with the average value of $-11.15 \%$ (Tabs. 2 and 3 ). This difference cannot be caused by altitudinal effect on isotope content of precipitation (supposed to be $0.09-0.15 \%$ of $\delta^{18} \mathrm{O}$ difference in $100 \mathrm{~m}$ of altitude, see previous text), as the altitude Vienna - Höhe Warte station is $203 \mathrm{~m}$ asl and average altitude of the Triassic carbonate range $344.0 \mathrm{~m}$ asl.

It is clear, that groundwater recharge is not supplied by all precipitation, and hence, only an appropriate part of precipitated water masses should be under consideration. In the moderate climate of Central Europe, generally the winter part of precipitation is supposed to be able to infiltrate, reach groundwater table and recharge the aquifer (Hanzel et al. 1984). For winter part of precipitation, the Vienna - Höhe Warte data give weighted average results $-12.31 \%$ for $\delta^{18} \mathrm{O}$ in the period $1961-1987$ and similar value $-12.37 \%$ for $1988-1989$ weighted average.

To calculate $\delta^{18} \mathrm{O}$ in recharging part of precipitation (effective precipitation) we used Thornthwaite's (Thorn- 
thwaite 1948; Thornthwaite \& Mather 1955) method of mean potential evapotranspiration calculation with monthly calculation steps. Potential evapotranspiration value was transformed to actual monthly evapotranspiration. In this process, a balance of monthly precipitation totals, monthly potential evapotranspiration and soil water content was examined to determine the real quantity of evaporated water. For estimation of potential evapotranspiration, only temperature and precipitation - two fundamental climatologic variables - are needed. These are measured directly on Vienna - Höhe Warte WMO station. For actual monthly evapotranspiration, also field capacity volume (in $\mathrm{mm}$ ) - the total saturation index of soil - is required. To obtain realistic data for the Brezovské Karpaty Mts., value of $90 \mathrm{~mm}$ was applied. This algorithm gave the recharge value of $165 \mathrm{~mm}$ $\left(5.24 \mathrm{~L} \cdot \mathrm{s}^{-1} \cdot \mathrm{km}^{-2}\right)$ - a realistic value, close to observations within the region.

After the linking of effective precipitation to Vienna - Höhe Warte datasets, it was visible that recharge could take place only during several months a year. On Fig. 8, the grey vertical bars show the isotopic composition of precipitation in the respective months (data series Höhe Warte PRECIP all), while blue vertical bars (Höhe Warte PRECIP rech) show only these portions of precipitation, which are really recharging. Here $\delta^{18} \mathrm{O}$ values, also in recharging parts of precipitation, are varying a lot. The value of standard deviation is $4.31 \%$ for precipitation in all months, and $4.26 \%$ for precipitation in really recharging months. Weighted averages calculated for $\delta^{18} \mathrm{O}$ in possible recharge during the period of 1961-1987 are $-13.04 \%$ and more depleted value of $-13.67 \%$ o weighted average was calculated for 1988-1989. These data are shown as blue horizontal lines on Fig. 8 - data series "Höhe Warte 1961-1987 AVG unevap" by solid line, "Höhe Warte 1988-1989 AVG unevap" by dashed blue line. The very depleted value of the 1988-1989 period, lower in $0.59 \%$ from the 1961-1987 average, was caused by extremely light precipitation of $62 \mathrm{~mm}$ in February, 1988: $-17.50 \%$.

We should note that calculated "unevaporated" values are even more far from the oxygen isotope content of groundwater to be found in monitored springs, than the precipitation simple average value. In comparison with the average value of groundwater in these springs $(-11.15 \%)$, data supposed to represent the "realistic recharge" are lighter by $-1.89 \%$ (1961-1988) or by $-2.52 \%$ o (1987-1989).

This situation could perhaps be explained by slightly different isotope composition of precipitation, like is visible from oxygen isotope data from relevant Slovak stations (Michalko 1998). For the years 1988-1989, arithmetic means of $\delta^{18} \mathrm{O}$ in cumulated monthly precipitation were $-11.42 \%$ for Bratislava hydrometeorological station (altitude 286 $\mathrm{m}$ asl; $45 \mathrm{~km}$ SSW from the site) and $-7.84 \%$ for station Topolníky (112 m asl; $66 \mathrm{~km}$ SSE from the site; $117 \mathrm{~km}$ ESE from Vienna). Cumulated monthly precipitation during 1988-1997 gave arithmetic mean for $\delta^{18} \mathrm{O}$ of $-8.28 \%$ for Bratislava and 9.05\% for station Topolníky, and for winter months $-11.31 \%$ and $-10.17 \%$ respectively. Also, in another explanation, groundwater discharging in evaluated springs of the Brezovské Karpaty Mts. is of different origin (maybe older) than water in the recent snowfall and rainfall as recorded in recent GNIP stations.

More probably, some additional fractionation processes take place between precipitation and discharge
Fig. 8: Values of $\delta^{18} \mathrm{O}$ in precipitation on the Vienna - Höhe Warte GNIP station (vertical bars) and measured in groundwater from springs Vitek, Spod javora, Stužková, Tri mlynky (points) in the period of 1988-1989. Horizontal lines represent weighted averages of $\delta^{18} \mathrm{O}$ in the periods of 1961-1987 and 1988-1989, both for all measured volumes as well as for calculated "unevaporated" volumes of precipitation. 
- post-depositional processes especially on the surface snow layers sensu Ekaykin et al. (2009), However, the water in the springs still keeps some connection to the processes of recharge (e.g., $\delta^{18} \mathrm{O}$ minimum in January, 1989 - maybe a response to February, 1988 extreme). We assume that in this case, the most important role plays as well sublimation of snow, which causes enrichment of snow on heavy isotopes (Ingraham in Kendall \& McDonnel 2000). According to Earman (2003), snowpack alteration affects the magnitude of isotopic shift: where melt takes place quickly, the isotopic shift is smaller than at sites where large amounts of snowfall and low temperatures allow long periods of alteration. In all cases, the data presented above demonstrate that it is not possible to link the oxygen isotope content in precipitation (even "unevaporated") directly to oxygen isotope content within the aquifer, without additional estimation of further isotope fractionation processes. For comparisons of isotope altitudinal effects in groundwater, one should concentrate on groundwater data in the first order.

\section{CONCLUSIONS}

A hydrograph separation technique, using the iterative solution of several exponential and linear equation members, was developed and applied on the discharge time series of the four karstic springs in the Brezovské Karpaty Mts. Such hydrograph separation technique is based on a presumption, that the discharge depends on the level of aquifer saturation by groundwater, and that the same discharge reflects the same groundwater saturation (piezometric level) in the aquifer. Every spring is described by unique, constant values of starting discharges $Q_{0}$ and recession coefficients for each detected subregime. Every spring's measured discharge value $Q_{t}$ is then determined just by a representative time $t$, i.e., theoretical elapsed time from the overall maximum discharge value $Q_{\max }$. Subsequently, proportional amounts of different discharging subregimes can be calculated for every moment of evaluated period. These proportional amounts can be linked to various components analysed for the same moment, in order to obtain the end members of the theoretical mixture.

Both $\delta^{18} \mathrm{O}$ and groundwater temperature forecast for $100 \%$ representation of each groundwater discharging subregime was performed for four karstic springs - Vítek, Stužková, Spod javora and Tri mlynky. All the basic ( $1^{\text {st }}$ laminar) subregimes showed similar oxygen isotope composition of water (median -11.17\%0), not very different from the overall median value $(-11.13 \%$ ), as this flow component represents $83.6 \%$ in all springs' average here. Spring Spod javora was the exception $(-14.45 \%)$. Also turbulent subregime in this spring seem to be unrealistically exaggerated in calculated water temperatures, and also extremely high content of oxygen-18 $(-5.24 \%)$. The reason for these very unprobable results are supposed to be caused by the poor quality of manually recorded discharge data by local observer. In the case of "more reliable" Vitek spring, the water outflowing both in $2^{\text {nd }}$ laminar and turbulent subregimes seems to be more depleted in $\delta^{18} \mathrm{O}(-11.65 \%$ and $11.53 \%$ ).

All the four monitored karstic springs in the $\mathrm{Br}$ ezovské Karpaty Mts. seem to have similar and stable oxygen isotope composition of water $(-11.15 \%$ in average), different from 1961-1987 weighted average on IAEA/WMO GNIP Vienna Höhe Warte station (203 m asl, $100 \mathrm{~km}$ SW from the investigated area; $-9.57 \%$ ). This difference cannot be explained by the recharge of only winter part of precipitation (weighted average results $-12.31 \%$ for Vienna - Höhe Warte) or net recharge calculated by Thornthwaite's method $(-13.04 \%$ for Vienna). Additional isotope fractionation processes, taking place between precipitation and discharge (sublimation - post-depositional processes on the surface snow layers) prohibit us to link the oxygen isotope content in precipitation (even "recharging" or "unevaporated") directly to oxygen isotope content within the aquifer. For comparisons of isotope altitudinal effects in groundwater, merely groundwater data should be used.

Hydrograph separation method, based on iterative solution of set of several simple exponential and linear equations, is based on a simplified understanding of karst system reality: the same discharge should reflect the same groundwater saturation (piezometric) level in the aquifer. In reality, several piezometric levels should exist at least for each saturated system (small fissures, medium fissures, karst conduits), if not for their different parts. Time dependency of these individual piezometric levels then substantially differs one from another. Király (2003) underlines the role of mixing processes and dilution within the aquifer and shows that improperly used chemical or isotopic hydrograph separation methods may lead to invalid inferences regarding the groundwater flow processes. However, in many times spring's discharge is the only quantitative reference value 
that describes the whole system. Simplified hydrograph separation method, based on proper recession curves analyses of the whole discharge time series, can help to distinguish and quantitatively express basic proportions of individual flow components in such cases. Without reliable recession curves, this relatively easy calculation of flow components can produce erroneous results. As demonstrated on sparsely populated datasets and manually collected discharge records in this paper, this method still seem to represent a perspective for quantitative referencing of small sample datasets to flow components.

\section{ACKNOWLEDGEMENT}

Data on oxygen isotope content in precipitation from the Vienna Höhe Warte station, used in this study, were retrieved from the GNIP/ISOHIS and WISER Database. These were analysed in the Isotope Hydrology Laboratory of the International Atomic Energy Agency (IAEA). The GNIP/ISOHIS and WISER Database is maintained by the International Atomic Energy Agency (IAEA) in cooperation with the World Meteorological Organiza- tion (WMO). Data on precipitation monthly precipitation totals and monthly averages of the air temperature from the WMO meteorological station Vienna Höhe Warte were also used in this study. The authors would also like to acknowledge the valuable comments of Bob Criss, who had in detail reviewed the first version of the paper, and the second anonymous reviewer, that helped us to significantly improve this paper.

\section{REFERENCES}

Barnes, B.S., 1939: The structure of Discharge-Recession Curves.- Trans. Amer. Geophys. Un. Part IV, 721-725.

Bates, B.C. \& P.K. Davies, 1988: Effect of baseflow separation procedures on surface runoff models.- Journal of Hydrology, 103, 309-322.

Began, A., Hanáček, J., Mello, J. \& J. Salaj, 1984: Geologická mapa Myjavskej pahorkatiny, Brezovských a Čachtických Karpát.- SGÚ, GÚDŠ, Slovenská kartografia, Map sheet 1 : 50 000.- Bratislava.

Bella, P., Hlaváčová, I. \& P. Holúbek, (eds.) 2007: Zoznam jaskýň Slovenskej republiky.- Slovenské múzeum ochrany prírody a jaskyniarstva, Správa slovenských jaskýň, Slovenská speleologická spoločnost', ISBN 978-80-88924-63-0, pp. 364 , Liptovský Mikuláš.

Binet, S., Mudry, J., Bertrand, C., Guglielmi, Y. \& R. Cova, 2006: Estimation of quantitative descriptors of northeastern Mediterranean karst behavior: multiparametric study and local validation of the SiouBlanc massif (Toulon, France).- Hydrogeology Journal, 14, 7, 1107-1121.

Boussinesq, J., 1877: Essai sur la theories des eax courantes.- Memoires presentes par divers savants a l'Academie des Sciences de l'Institut National de France, Tome XXIII, No. 1.
Browne, T.J., 1978: An analysis of low streamflow recession curves in Devon.- Rep. Trans. Devon. Assoc. Adv. Sci., 110, 81-94.

Cooper, H.H. jr. \& M.I. Rorabaugh, 1963: Groundwater movements and bank storage due to flood stages in surface streams.- USGS Water Supply Paper 1536-J, 343-366.

Chapman, T., 1999: A comparison of algorithms for stream flow recession and baseflow separation.- Hydrol. Processes, 13, 701-714.

Dreiss, S.J., 1989: Regional scale transport in a karst aquifer; 1 . Component separation of spring flow hydrographs.- Water Resources Research, 25, 1, 117125.

Drogue, C., 1972: Analyse statistique des hydrogrammes de décrues des sources karstiques.- Journal of hydrology, 15, 49-68.

Earman, S., 2003: Stable Isotopes in Snow: Implications for the Design of Precipitation Collectors and Studies of Groundwater Recharge.- Eos Trans., American Geophysical Union, 84, 46, Fall Meet. Suppl., Abstract \#H21D-0890.

Ekaykin, A.A., Hondoh, T., Lipenkov, V.Y. \& A. Miyamoto, 2009: Post-depositional changes in snow isotope content: preliminary results of laboratory experiments.- Climate of the Past Discussions, 5, 2239-2267. 
Epstein, S. \& T.K. Mayeda, 1953: Variations of the ${ }^{18} \mathrm{O} /{ }^{16} \mathrm{O}$ ratio in natural waters.- Geochimica et Cosmochimica Acta, 4, 5, 213-224.

Forkasiewicz, J. \& H. Paloc, 1967: Le régime de tarissement de la Foux de la Vis.- Chronique d'hydrogéologie, 10, 59-73.

Goldscheider, N. \& D. Drew, (eds.) 2007: Methods in Karst Hydrogeology.- International contributions to hydrogeology, 26, International Association of Hydrogeologists, Taylor \& Francis, pp. 264, London.

Griffiths, G.A. \& B. Clausen, 1997: Streamflow recession in basins with multiple water storages.- Journal of Hydrology, 190, 60-74.

Hanzel, V., Kullman, E., Dovina, V., Franko, O., Škvarka, L. \& K. Vrana, 1984: Podzemné vody Slovenska a prognózy ich využitia [Groundwater in Slovakia and prognoses of its use (in Slovak)].- State Geological Institute of Dionýz Štúr, Report No. 60252, pp. 277.

Hino, M. \& M. Hasebe, 1986: Separation of a storm hydrograph into runoff components by both filterseparation Ar method and environmental isotope tracers.- Journal of Hydrology, 15, 251-264.

Horton, R.E., 1933: The role of infiltration in the hydrological cycle.- Trans. Am. Geophys. Union, 14, 446-460.

Hooper, R.P. \& C.A. Shoemaker, 1986: A comparison of chemical and isotopic hydrograph separation.- Water Resources Research, 22, 10, 1444-1454.

IAEA/WMO, 2006: Global Network of Isotopes in Precipitation. The GNIP Database.- [Online] Available from: http://isohis.iaea.org [Accessed 27 ${ }^{\text {th }}$ May 2006].

James, L.D. \& W.O. Thompson, 1970: Least squares estimation of constants in a linear recession model.Water Resources Research, 6, 4, 1062-1069.

Kendall, C. \& J.J. McDonnel, (eds.) 2000: Isotope tracers in catchment hydrology.- Second edition, Elsevier, pp. 839, Amsterdam.

Király, L., 2003. Karstification and Groundwater Flow / Speleogenesis and Evolution of Karst Aquifers.- In: Gabrovšek, F. (ed.) Evolution of karst: from prekarst to cessation. Zalozba ZRC, pp. 155-190, PostojnaLjubljana.

Kovács, A., 2003: Geometry and hydraulic parameters of karst aquifers - A hydrodynamic modelling approach.- PhD. thesis, La Faculté des sciences de l'Université de Neuchâtel, Suisse, pp. 131.

Kresic, N.A., 1993: Review and selected bibliography on quantitative definition of karst hydrogeological systems.- In: LaMoreaux, P.E. et al. (eds.) Annotated bibliography of Karst Terranes. International Contributions to Hydrogeology, 14, pp. 51-87, Hannover.
Kulandaiswamy, V.C. \& S. Seetharaman, 1969: A note on Barnes' method of hydrograph separation.- Journal of Hydrology, 9, 222-229.

Kullman, E., 1983: Režim podzemných vôd s turbulentným prúdením v puklinovo-krasovom horninovom prostredí [Groundwater regime with turbulent flow in fissure-karst rock environment (in Slovak)].- Geologické práce, 79, 237-262.

Kullman, E., 1990: Krasovo-puklinové vody. Karst-fissure waters.- Geologický ústav Dionýza Štúra, pp. 184 , Bratislava.

Kullman, E., 2000: Nové metodické prístupy k riešeniu ochrany a ochranných pásiem zdrojov podzemných vôd v horninových prostrediach s krasovo-puklinovou priepustnostou [New methods in groundwater protection and delineation of protection zones in fissure-karst rock environment (in Slovak)].- Podzemná voda, VI., 2, 31-41.

Lakey, B. \& N. C. Krothe, 1996: Stable Isotopic Variation of Storm Discharge from a Perennial Karst Spring, Indiana.- Water Resources Research, 32, 3, 721-731.

Lamb, R. \& B. Keith, 1997: Using interactive recession curve analyses to specify a general catchment storage model.- Hydrology and Earth System Sciences, $1,101-113$.

Linsley, R.K., Kohler, M.A. \& J.L.H. Paulhus, 1982: Hydrograph analyses.- In: Linsley, R.K. et al. (eds.) Hydrology for Engineers. McGraw-Hill, pp. 254-287, New York.

Maillet, E., 1905: Essais d'Hydraulique Souteeraine et Fluviale.- Hermann Paris, pp. 218, Paris.

Malík, P., Kullman, E. \& K. Vrana, 1992: Hydrogeológia karbonátov mezozoika Brezovských Karpát [Hydrogeology of Mesozoic carbonate rocks in Brezovské Karpaty Mts. (in Slovak)].- Západné Karpaty, sér. hydrogeol. a inž. geol., 10, 53-98.

Malík, P., Michalko, J. \& S. Rapant, 1993: Štruktúrno-hydrogeologická analýza karbonátov triasu krížñanského príkrovu vo Velkej Fatre [Structural-hydrogeologic analyses of Krížna nappe Triassic carbonates in the Velká Fatra Mts. (in Slovak)].- Manuscript - Archive of the Geofond Branch, State Geological Institute of Dionýz Štúr, Arch. No. 79413, pp. 277 , Bratislava.

Malík, P., 2007: Assessment of regional karstification degree and groundwater sensitivity to pollution using hydrograph analysis in the Velka Fatra Mts., Slovakia.- Water Resources and Environmental Problems in Karst. Environmental Geology, 51, 707-711. 
Michalko, J., 1998: Izotopová charakteristika podzemných vôd Slovenska [Isotope characteristics of Slovak groundwaters (in Slovak)].- Kandidátska dizertačná práca, PhD. Thesis, Slovak Academy of Sciences, pp. 94.

Nathan, R.J. \& T.A. McMahon, 1990: Evaluation of Automated Techniques for Base Flow and Recession Analyses.- Water Resources Research, 26, 7, 14651473.

Padilla, A., Pulido Bosch, A. \& A. Mangin, 1994: Relative importance of baseflow and quickflow from hydrographs of karst spring.- Ground Water, 32, 267-277.

Pettyjohn, W.A. \& R. Henning, 1979: Preliminary estimate of ground-water recharge rates, related streamflow and water quality in Ohio.- Ohio State University Water Resources Centre Project Completion Report No. 552, pp. 323.

Pereira, L.S., 1977: Etudes de tarissement sur des petits basins versants de montagne.- Rapport 12/77 de 1'Institut d'Hydromécanique et d'Aménagement des Eaux de l'Ecole Polytechnique Fédérale de Zurich.

Pereira, L.S. \& H.M. Keller, 1982: Factors affecting recession parameters and flow components in eleven small Pre-Alp basins.- IAHS Publ., 138, 233-242.

Posavec, K., Bačani, A. \& Z. Nakić, 2006: A visual basic spreadsheet macro for recession curve analysis.Ground Water, 44, 5, 764-767.

Rutledge, A.T., 1998: Computer Programs for Describing the Recession of Ground-Water Discharge and for Estimating Mean Ground-Water Recharge and Discharge from Streamflow Records-Update.- U.S. Geological Survey, Water-Resources Investigations Report 98-4148, pp. 43.
Rúčka, I., 1998: Preparačné metódy na izoláciu stabilných izotopov kyslíka a vodíka $\mathrm{z}$ vôd [Preparation methods for oxygen and hydrogen stable isotopes in waters (in Slovak)]. Zborník $z$ XXXIII. ročníka seminára Hydrochémia '98, Bratislava, VÚVH , 176-182, Bratislava.

Sloto, R.A. \& M.Y. Crouse, 1996: HYSEP: A computer program for streamflow hydrograph separation and analysis.- U.S. Geological Survey Water-Resources Investigations Report 96-4040, pp. 46,.

Talarovich S.G. \& N.C. Krothe 1998: Three-Component Storm Hydrograph Separation of a Karst Spring Contaminated by Polychlorinated Biphenyls in Central Indiana.- Environmental Geosciences, 5, 4, $162-176$.

Tallaksen, L.M., 1995: Review of baseflow recession analysis.- Journal of Hydrology, 165, 349-370.

Thornthwaite, C.W., 1948: An approach toward a rational classification of climate.- Geograph. Rew., 38, 55-94.

Thornthwaite, C.W. \& J.R. Mather, 1955: The water balance. Publ. in Climatology, 8, pp. 104.

Trček, B., Veselič, M. \& J. Pezdič 2006: The vulnerability of karst springs - a case study of the Hubelj spring (SW Slovenia).- Environmental Geology, 49, 865874 .

Wittenberg, H. \& M. Sivapalan, 1999: Watershed groundwater balance estimation using stream-flow recession analysis and baseflow separation.- Journal of Hydrology, 219, 20-33.

Yevjevich, V. (ed.) 1976: Karst hydrology and water resources.- Proc. of the U.S.-Yugoslavian Symp., Dubrovnik 1975, Water Resources Pub., Vol. 1-2, pp. 873, Fort Collins, U.S. 